BRIEF REPORT

\title{
Lessons for increasing awareness and use of booster seats in a Latino community
}

\author{
J W Lee, K Fitzgerald, B E Ebel
}

Injury Prevention 2003;9:268-269

\begin{abstract}
Objectives: Latino children are more likely to be unrestrained passengers in motor vehicles than nonLatino children, but little is known about the use of booster seats in Latino families. This study investigates Latino parents' knowledge, attitudes and beliefs about booster seats, barriers to booster seat use, and effective strategies for message delivery in the Latino community.

Methods: Two focus groups were conducted with Spanish speaking parents. Information was obtained through a written survey and moderated discussions.

Results: Parents were widely misinformed about recommended guidelines for booster seat use, and the majority of participants did not own a booster seat. Parents identified a lack of information, the cost of booster seats, resistance to use by the child or the father, limited space in the vehicle, and unavailability of shoulder belts as barriers to booster seat use. Participants felt that learning more about the new Washington state booster seat law and its consequences would increase booster seat use. Public health messages felt to be effective were those in Spanish, delivered by credible spokespeople such as physicians and teachers, and utilizing the Spanish media. Conclusions: Campaigns to promote booster seats in the Latino community should be culturally specific, and clear guidelines for booster seat use should be given in Spanish. Legislation may be an important incentive for using booster seats, though reducing their cost and providing strategies to address child resistance and physical constraints of some vehicles are also important.
\end{abstract}

Dr Josie W Lee, c/ Madrona Medical Group, 4545 Cordata Parkway, Bellingham, WA 98226, USA;

josie_w_lee@yahoo.com

M otor vehicle collisions remain the leading cause of death in children between $4-8$ years of age. ${ }^{1}$ The additional risks of injury inflicted on young children by premature use of seatbelts are well documented, and include head, spine, and abdominal injuries, the so-called "seatbelt syndrome" ${ }^{\prime 2}{ }^{3}$ Seatbelt positioning booster seats have been shown to reduce serious injury in children aged $4-8 .^{3}$ It is recommended that booster seats be used until children reach 8 years, 80 pounds $\left(36 \mathrm{~kg}\right.$ ), and 4 feet 9 inches $(1.45 \mathrm{~m})$ tall. ${ }^{4}$ In 2000, Washington became the first of 13 states to pass booster seat legislation. ${ }^{6}$ However, most parents are still not using booster seats for their children; national estimates suggest that only $19 \%$ of age appropriate children are currently riding in booster seats. ${ }^{7}$

Latinos comprise the largest minority group in Washington State, making up $7.5 \%$ of the general population, and $11.8 \%$ of children aged $0-18 .{ }^{8}$ A recent study found that Latino children in Washington were one third less likely to use a booster seat than non-Latino children. ${ }^{9}$ Previous work has shown that language differences and cultural barriers may have hindered the adoption of seatbelts and child safety restraints by Latino families. ${ }^{10}{ }^{11}$ However, it has also been shown that culturally appropriate outreach programs tailored to the Latino community have been successful in increasing the use of child restraints. $^{12}$ A literature search found no published data describing the specific knowledge, attitudes, and beliefs of Latinos regarding booster seat use. With the goal of instituting promotional campaigns targeting the Latino community, we conducted focus groups with Latino parents to aid in developing outreach strategies.

\section{METHODS}

Two focus groups were held at community centers in two different neighborhoods with relatively high Latino populations in the greater Seattle area. Parents were eligible if they were Spanish speaking, had children under the age of 10 years, and owned or drove a car. Participants were recruited by a member of the research team, who went to each of the centers and signed up parents who were interested and met participation criteria. Child care was provided on-site for participants, along with food and beverages.

The groups were conducted in Spanish by members of the research team with the aid of a bilingual facilitator. Participants completed a brief initial survey to note the age and weight of their children, and the restraint systems available in their vehicle. Parents were asked to share their beliefs about when a child was big enough to use only an adult seatbelt. They were also asked whether they were aware of the Washington state booster seat law.

Topics of discussion during the focus groups included current knowledge and attitudes regarding booster seats, barriers and reinforcing factors for booster seat use, current campaign messages, and effective methods for message delivery. The results of the focus groups were audiotaped and reviewed by the authors to identify important themes. After completing the sessions, participants were paid $\$ 20$ in cash and given discount coupons for $\$ 10$ off the cost of a booster seat at a local retail store. Booster seat educational materials in English and Spanish were also made available to participants and their children.

The project was reviewed by the University of Washington Institutional Review Board and granted exempt status for the purpose of preliminary data collection for program development.

\section{RESULTS}

\section{Initial survey}

There were 23 participants ( 12 in the first group and 11 in the second), of whom all but two were women. All parents reported using some type of safety restraint device for each of their children, but of the 18 children who were aged 4-8 and/or weighed 40-80 pounds (18-36 kg), parents reported that only two used booster seats. Many parents had never heard of booster seats, and all participants were uncertain about the age and weight guidelines for booster seat use. Ten out of 21 respondents had heard of the new booster seat legislation in Washington State, which went into effect approximately two months before the focus groups were held. 
Reported sources of information about booster seats were television and radio news programs, newspaper articles, health clinics, the Department of Motor Vehicles, community centers, police officers, and friends. The majority of information had been received in Spanish.

\section{Barriers and reinforcing factors}

Parents felt that barriers to booster seat use for Latino families may include a lack of information about booster seats, resistance to use by the child, the cost of booster seats, inconvenience, lack of space in the vehicle to accommodate all of the necessary child safety seats for large families, and the lack of shoulder belts in the rear seats of older vehicles. Many of the female participants felt that their husbands would be less likely to enforce booster seat use due to lack of knowledge or failure to use safety restraints themselves. Several participants stated that seatbelts and child safety restraints were not commonly used in their native countries, which may contribute to the lack of awareness and low perception of risk among Latinos.

The booster seat law and the monetary fine for non-use were felt to be major incentives for booster seat use. The use of seatbelts by the parents themselves, as well as the enforcement of booster seat use by both parents, was felt to be crucial in reinforcing the child's use of the proper safety restraint device. Parents believed strongly that school aged children needed to be educated about booster seats in schools and child care centers. This would serve both to decrease their resistance to using the seats, as well as allow them to educate and encourage their parents to provide and enforce the use of booster seats.

\section{Campaign messages}

Participants were asked to evaluate current booster seat campaign materials, such as posters, billboards, and brochures. All parents preferred the materials that were in Spanish. Parents generally liked materials that were colorful, easily caught their attention, and had succinct and clearly written guidelines for booster seat use along with pictures of children properly restrained in a vehicle.

The Spanish media (television, radio, newspapers) were seen as powerful tools for delivering information to a large population. Parents felt that television news programs or public service announcements would be effective, especially when played during popular programs, such as "telenovelas" (soap operas) to reach women and sports programs to reach men. Stories about real children injured or killed in the setting of improper restraint in a vehicle were felt to be compelling and convincing, and parents cited examples of current public health messages using these tactics, such as antismoking and bicycle helmet campaigns.

Educational sessions associated with booster seat discount opportunities or giveaways held at an established gathering place were felt to be an excellent way of distributing information and reducing the cost of a booster seat. Parents identified health care providers, teachers, and law enforcement officers as credible spokespeople for child safety issues. Many mothers felt there was a need for more educational efforts targeted specifically at fathers, who often were working and therefore not present during potential teachable moments such as doctor visits, or school and community events.

\section{DISCUSSION}

Previous focus groups have shown that most parents have insufficient knowledge about booster seats and their recommended use. ${ }^{13}$ Despite the recent implementation of a booster seat law in the state of Washington, there remains a lack of awareness among Latino parents regarding booster seats. There are also significant barriers contributing to the low rates of booster seat use in this population. Lowering the cost of booster seats through discount programs and giveaways may be a useful enabling factor for some Latino families. The lack of shoulder belt availability in many older vehicles, and limited seating positions for large families, are barriers for which there are few easy solutions at present. It should also be recognized that while Latino men may be key decision makers in their families regarding car safety issues, the perceptions of risk and barriers to booster seat use among Latino fathers may differ from those shared by the largely female participants in this study.

Comprehensive, community based public health campaigns can be effective in increasing use of injury prevention strategies, ${ }^{14} 15$ including increasing booster seat use. ${ }^{16}$ However, language and cultural differences may lessen the effectiveness of such campaigns among ethnic minority groups. Our focus group members stressed the importance of culturally appropriate messages about booster seats. Their suggestions for delivering messages in Spanish, clearly stating age and weight guidelines for booster seat use, emphasizing the legal and child injury consequences of booster seat non-use, using respected sources of information, and targeting messages to mothers, fathers, and children will be incorporated into a Latino outreach campaign.

\section{Authors' affiliations}

J W Lee, B E Ebel, Department of Pediatrics and the Harborview Injury Prevention and Research Center, University of Washington, Seattle, Washington

K Fitzgerald, Children's Hospital and Regional Medical Center, Seattle, Washington

\section{REFERENCES}

1 Centers for Disease Control. Working to prevent and control injury in the United States: fact book for the year 2000. Atlanta, GA: US Department of Health and Human Services, CDC, 2000.

2 Anderson PA, Rivara FP, Maier RV, et al. The epidemiology of seatbelt-associated injuries. J Trauma 1991;31:60-7.

3 Durbin DR, Elliot MR, Winston FK. Belt-positioning booster seats and reduction in risk of injury among children in vehicle crashes. JAMA 2003;289:2835-40.

4 National Highway and Traffic Safety Administration. Available at: http://www.nhtsa.gov/people/injury/childps/ (accessed 7 November 2002).

5 American Academy of Pediatrics. Available at: http://www.aap.org/ family/carseatguide. htm (accessed 7 November 2002).

6 Anton Skeen Act: Washington child restraint law. Revised Code of Washington (RCW) 46.61.687. 2000 regular session ed, 2000, http://www.leg.wa.gov/RCW/ index.cfm?fuseaction=section\&section $=46.61 .687$ (accessed 5 August 2003)

7 Cody B, Mickalide A, Paul H, et al. Child passengers at risk in America: a national study of restraint use. Washington, DC: National SAFE KIDS Campaign, 2002

8 US Census Bureau. Census 2000. Available at: http:// quickfacts.census.gov/qfd/states/53000.html laccessed 7 November 2002).

9 Lovrich NP, Stehr SD. An assessment of child car safety restraint in the State of Washington: a baseline survey. Pullman, WA: Washington State University, 2001.

10 Stiles MC, Grieshop Jl. Impacts of culture on driver knowledge and safety device usage among Hispanic farm workers. Accid Anal Prev 1999;31:235-41.

11 National Highway Traffic Safety Administration. Highway safety needs of US Hispanic communities: issues and strategies. DOT HS 808 373. Washington, DC: NHTSA, 1995.

12 Istre GR, McCoy MA, Womack KN, et al. Increasing the use of child restraints in motor vehicles in a Hispanic neighborhood. Am J Public Health 2002:92:1096-9.

13 Rivara FP, Bennett E, Crispin B, et al. Booster seats for child passengers: lessons for increasing their use. Inj Prev 2001;7:210-13.

14 Klassen TP, MacKay JM, Moher D, et al. Community-based injury prevention interventions. In: Behrman RE, ed. The future of children. Unintentional injuries in childhood. Los Altos, CA: Packard Foundation, 2000: 83-110.

15 Hanfling MJ, Mangus LG, Gill AC, et al. A multifaceted approach to improving motor vehicle restraint compliance. Inj Prev 2000;6:125-29.

16 Ebel BE, Koepsell TD, Bennett EE, et al. Use of child booster seats in motor vehicles following a community campaign. JAMA 2003;289:879-84. 